\title{
WHO SUES FOR DIVORCE? FROM FAULT THROUGH FICTION TO FREEDOM
}

\author{
LAWRENCE M. FRIEDMAN* and ROBERT V. PERCIVAL**
}

I $I_{F}$, in a society, men and women had complete equality, in law and in fact, and if divorce were cheap, easy to get, carried no stigma, and had no adverse legal consequences, we would expect little or no difference in the number of husbands and wives who filed for divorce. In fact, in this imaginary society it would make no difference who actually filed; the law might even allow joint filing. It hardly needs to be said that this imaginary kingdom is not the United States. In America, men and women occupy different social roles. Divorce costs money-considerable money. The laws of the various states make divorce more or less time-consuming and inconvenient. The Catholic Church forbids divorce; divorce carries something of a stigma in many strata and among many groups; and the outcome of a divorce case has definite consequences for property settlement, child custody, and, in some places, the right to remarry. For a number of reasons, some of them rather obvious, it has been the general custom that the wife, not the husband, sues for divorce. But this was not always the case in all states; and we may be entering a period in which the pattern is changing. The answer to the question, who sues for divorce, is an indicator of some sensitivity, reflecting attitudes about the use of courts in family matters. This, therefore, is a study in legal culture, focussing on historical changes in the proportion of divorce proceedings initiated by either sex.

Before we proceed, it is important to state the limitations of the study. It does not, and cannot, deal with family life as such. It cannot measure adultery, desertion, unhappy marriages, family instability. These factors, of course, affect the divorce rate, and also the question of who sues for divorce. But the relationship is subtle and murky, and it would be foolish to leap from divorce statistics to conclusions about family life and family stability. This is most obvious for a country like Paraguay, which does not allow divorce at all, or South Carolina, which allowed no divorce in the 19th century. Obviously not every couple in Paraguay is happily married; but there is no divorce. Divorce has been common in the West for less than two centuries. Probably the prevailing view among elites during this period has

* Professor of Law, Stanford University.

** Law School and Department of Economics, Stanford University. 
been that easy divorce would be pernicious. Easy divorce would loosen the family structure and threaten the death of civilization. A minority view-now quite strong-takes the point of view (perhaps equally implausible) that laws of marriage and divorce have no effect at all on family stability and family life. This study makes no attempt to resolve this issue; it is an essay in the historical sociology of law, not of the family.

\section{American Divorce LaW: A Historical Sketch ${ }^{1}$}

Divorce was not imported with the common law from England. The mother country was a "divorceless society," and remained that way until 1857.2 Divorce existed, but only by act of Parliament; this was obviously for the wealthy and prominent only. The rest of the population had to settle for annulment, which was not easy to get, or the so-called divorce from bed and board, a form of legal separation that did not entitle either spouse to remarry. Marriages broke down, of course, but desertion and separation served as self-help divorce.

The English tradition was followed in the Southern colonies. Absolute divorce was unknown; divorce from bed-and-board and annulment very rare. ${ }^{3}$ In New England, however, courts and legislatures occasionally granted divorce. Pennsylvania in 1682 gave a married person the right to a "bill of divorcement" if the other partner was convicted of adultery. After Independence, divorce continued to be difficult and uncommon in the South. South Carolina prohibited divorce absolutely. In Georgia the Constitution in 1798 allowed a form of legislative divorce. Less than 300 Georgia marriages were dissolved before $1835 .^{4}$

Judicial divorce became the normal method of ending a marriage in the Northern states. Pennsylvania passed a general divorce law in 1785; Massachusetts in 1786. Every New England state had some form of divorce law before 1800. Divorce proceedings took an adversary form. Whoever filed for divorce, whether husband or wife, had to prove the other party guilty of committing some act-adultery, desertion-that by law was "grounds" for divorce. The moving party, on the other hand, had to be innocent.

The demand for divorce was tiny by modern standards. But the trend was steadily upwards. The sheer size of this demand ultimately sealed the fate of legislative divorce, which had survived in a number of states (for example,

1 On divorce in the United States see in general Nelson Blake, The Road to Reno (1962) ; Lawrence M. Friedman, A History of American Law 179-84, 535-40 (1973); Max Rheinstein, Marriage Stability, Divorce and the Law 28-50 (1972).

2 See Gerhard O.W. Mueller, Inquiry into the State of a Divorceless Society, Domestic Relations Law and Morals in England from 1660 to 1857,18 U. Pitts. L. Rev. 545 (1957).

32 George Elliott Howard, A History of Matrimonial Institutions 121-27 (1904).

4 Friedman, supra note 1 , at 182. 
New Jersey). Private bills of divorce became a nuisance, a drain on the legislature's time-just as private acts of incorporation had to be replaced by general laws. State after state abolished the legislative divorce, usually by constitutional provision.

From the very start, the states went their own separate way with regard to details of divorce law. There was a singular lack of conformity. In the middle of the nineteenth century, at a time when divorce was still difficult or even impossible in parts of the South, some Northern states had divorce laws liberal even by modern standards. In Connecticut, any misconduct was grounds for divorce if it "permanently destroys the happiness of the petitioner and defeats the purposes of the marriage relation." North Carolina, Indiana, and Rhode Island were also quite permissive. Most liberal of all was Maine. Here, a divorce could be granted when a majority of justices of the supreme judicial court considered it "reasonable and proper, conducive to domestic harmony, and consistent with the peace and morality of society." Other states relaxed their divorce laws to include (along with adultery, desertion, and impotence) such vague new grounds as "cruelty."

A reaction set in after 1870 . Militant feminists favored easy divorce $;^{7}$ but prominent moralists, clergymen, and jurists were horrified by the idea. Free divorce would lead to "general corruption," especially among the lower classes, "whose facilities for sensual gratification are so nearly unlimited." A New England Divorce Reform League was formed in 1881; Dr. Woolsey, President of Yale University, was its president. A National Divorce Reform League appeared in 1885. By 1883 both the Connecticut and Maine laws had been "reformed." Maine now required a six-month wait before decrees became "absolute;" plaintiff was not to remarry for two years without court permission; the defendant was indeed never free to remarry without leave of the court. ${ }^{\circ}$

Throughout the nineteenth century, the divorce rate was rising. There were 9,937 divorces in $1867,25,535$ in 1886. This is far more than any rise in population can explain, and it took place despite a tightening of the laws in the states that once were "loose."10 By 1900 more than 55,000 divorces were granted each year. Since then, the rate (as well as the absolute number) has continued to rise, interrupted only by brief upward leaps after the world wars and a temporary drop during the Depression (see Figure 1).

5 Act of June 19, 1849, ch. 21, [1849] Conn. Acts 17.

6 Law of July 13, 1847, ch. 13, \& 1, [1847] Maine Laws 8.

7 Elizabeth Cady Stanton, in The Need of Liberal Divorce Laws, 139 No. Am. Rev. 234,243 (1884).

8 Marriage and Divorce, 14 Albany L.J. 422, 425 (1876).

$9 \mathrm{Ch} .212, \S \S 1,3,4,[1883]$ Maine Laws 175-76.

10 Blake, supra note 1 , at 34 . 
THE JOURNAL OF LEGAL STUDIES

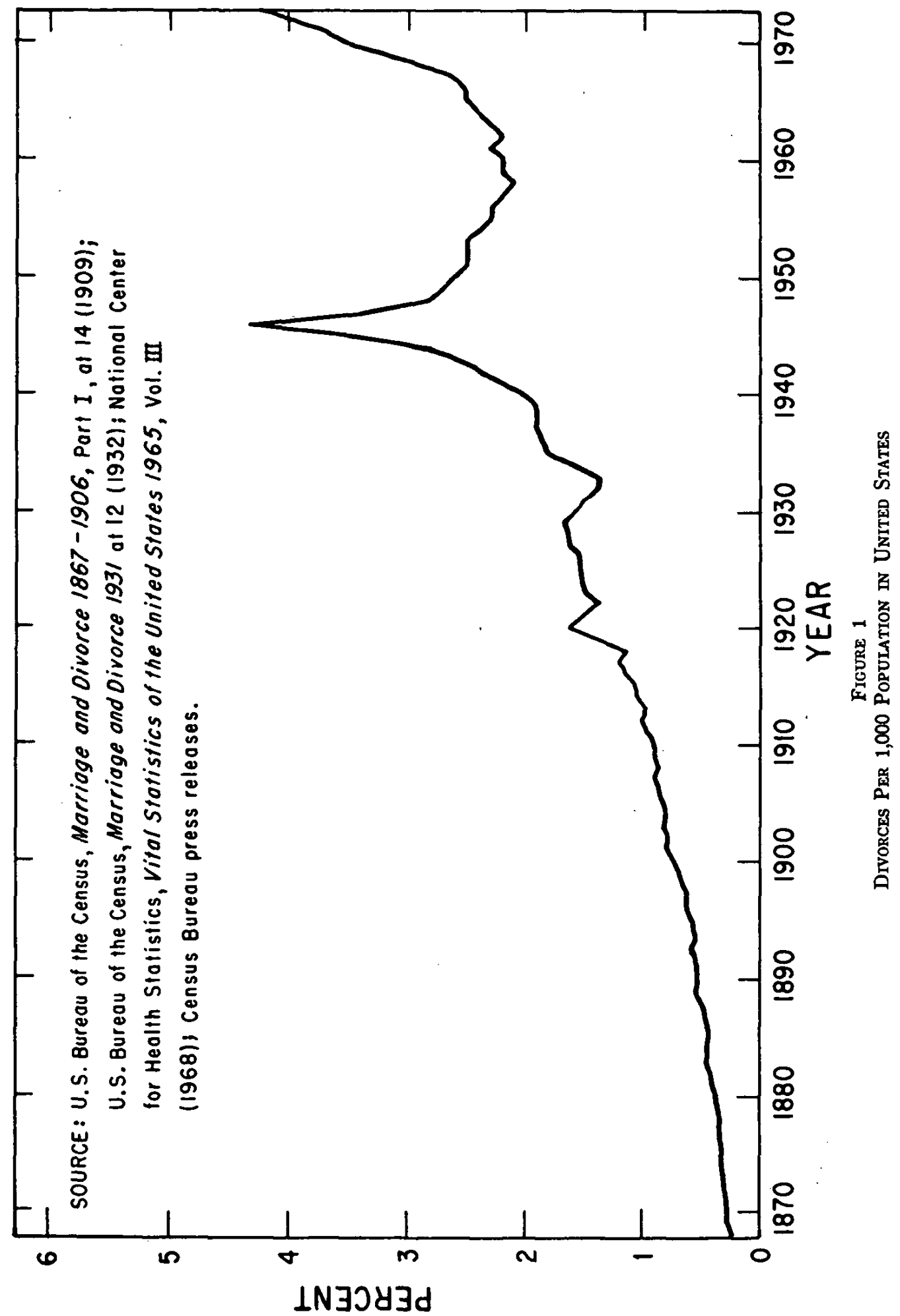


The law of divorce underwent relatively little change between the late nineteenth century and 1970. A suit for divorce continued to be, as before, an adversary proceeding in form. One had to allege and prove grounds. There were many bitter and unedifying battles, in which spouses aired their dirty linen in public, and contested their divorces in a stubborn or sensational way. But the collusive or friendly divorce became overwhelmingly the normal case. This was the situation where both wanted the divorce, or considered their marriage not worth fighting for, by the time the case reached court. Hence the nominal defendant failed to defend, and even helped in the plaintiff's case. It is hard to date the development of the collusive divorce exactly; but, as we shall see, it was the norm before the end of the nineteenth century.

Some states had more rigid statutes than others. Divorce in New York was, practically speaking, limited to adultery. Here collusion was an open scandal. Lawyers largely advertised their skill at arranging divorce. "Divorce rings" and manufactured adultery were New York specialties. Henry Zeimer and Waldo Mason, arrested in 1900, had hired young secretaries and other enterprising girls for this business. ${ }^{11}$ The girls would admit on the witness stand that they knew the plaintiff's husband, then blush, shed a few tears, and leave the rest to the judge. Annulments, too, were more common in New York than elsewhere; easy annulment was a loophole in the divorce lawsless distasteful, though less certain, than trumped-up adultery.

The friendly divorce was a much simpler matter in those states which allowed "cruelty" as grounds for divorce. It was easy to allege cruelty; and much less embarrassing to make out a case than was true of adultery. By 1890 cruelty had passed adultery in popularity as grounds for divorce; it was second only to desertion. While the percentage of divorces awarded for cruelty doubled in the 35 years following the Civil War, the percentage awarded for adultery was halved (see Figure 2).

The migratory divorce, for people with money and the urge to travel, was another detour around strict divorce laws. To attract the "tourist trade," a state needed easy laws and a short residence period. Indiana was a divorce mill until 1873, when the legislature passed a strict law, and put an end to the business. South and North Dakota, too, had brief careers as divorce mills. Finally, Nevada became the place. Earl Russell came to the Nevada side of Lake Tahoe for a divorce at the end of the nineteenth century, and Laura Corey, wife of the president of U.S. Steel, came to Reno in a blaze of

\footnotetext{
11 Friedman, supra note 1, at 437. In Maryland, too, adultery was practically the only grounds. Yet, in four out of ten cases in 1930, the plaintiff claimed to have direct evidence of adultery, or even that he or she saw the act done, although (as the authors of a study of divorce remarked caustically) "the uninitiated would suspect that acts of adultery are ordinarily carried on in private." 1 Leon C. Marshall \& Geoffrey May, The Divorce Court 26 (1932).
} 
THE JOURNAL OF LEGAL STUDIES

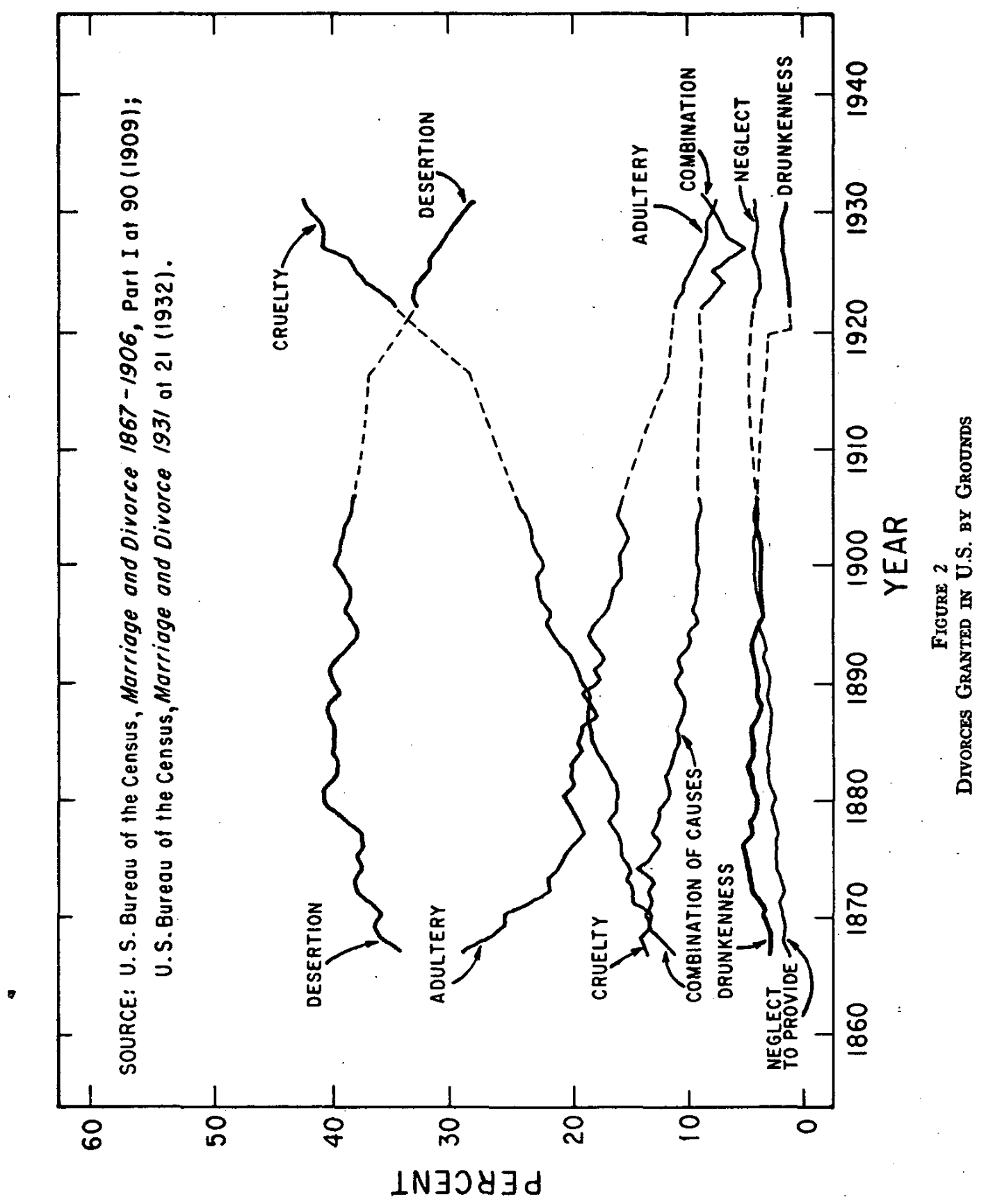


publicity in 1906; but Nevada law had its ups and downs, and the state really "took off" as a divorce mill only after Mary Pickford filed for divorce against Owen Moore in 1920.12 Nevada remained impervious to moralists, and its career as a national divorce mill has lasted longer than any other state. A few states looked with envy on the revenues that flowed into Reno and other Nevada cities. The Virgin Islands were an important rival. Arkansas, Florida, Idaho, and Wyoming also tried to compete; but the five jurisdictions accounted for less than 10 per cent of all American divorces in 1940.13 One problem (shared by Nevada) was the problem of the validity of these quick divorces-a problem that the Supreme Court frequently wrestled with:14

But there were broader pressures building up for reform--pressures more powerful than the greed of those who profited from divorce mills. These pressures began to make their mark on the law. In 1949 South Carolina finally gave up its struggle, and legalized divorce. In 1966, New York added new grounds for divorce to its statute-cruelty, abandonment, and two-years' separation.

These were straws in the wind. In 1969, California fired the first shot in a bloodless revolution. The legislature, effective January 1, 1970, abolished divorce as it had been classically constituted. In its place came "dissolution" of marriage - available when "irreconcilable differences" caused the "irremediable breakdown" of a marriage. ${ }^{15}$ Within two years, five other statesColorado, Florida, Iowa, Michigan and Oregon-adopted their own version of "no-fault" divorce. Essentially, in these states, with some variation (Iowa, for example, required counseling and a 90-day cooling-off period) divorce was available on demand. Other states, though unwilling to go quite so far, relaxed their old requirements. Separation for 18 months was added as a ground to New Jersey's statute in 1971. Vermont amended its law to allow divorce after six months' separation. No-fault-type standards of marital breakdown appeared as grounds for divorce in Idaho, New Hampshire, North Dakota and Texas. ${ }^{16}$

These recent legal changes do not, in fact, make much change in real standards for divorce. But they have significantly altered the formal rules-

12 Earl Pomeroy, In Search of the Golden West, the Tourist in Western America 187 (1957); Gilman M. Ostrander, Nevada, The Great Rotten Borough, 1859-1964, at 205-06 (1966).

13 Blake, supra note 1. Many of these divorces went to permanent residents of these states. Paul Jacobson estimates that migratory divorces were only 3 to $5 \%$ of the national total. Paul Jacobson, American Marriage and Divorce 109 (1959).

14 The problem is discussed in Rheinstein, supra note 1, at 65-81. See, e.g., Estin v. Estin, 334 U.S. 541 (1948).

15 Cal. Civil Code $\$ 4506$ (1970). On the "liberal breakthrough" in divorce in general, see Rheinstein, supra note 1, at 317-405.

16 Michael Wheeler, No Fault Divorce 32-49 (1974). 
and the costs and ease of divorce. Collusion meant that divorce on demand had been available in many states before, but at a stiff price, and with a certain element of hypocrisy. The new laws eliminate the adversary form; parties can agree to divorce without little white lies. In the first burst of legal permissiveness, the divorce rate has soared, equalling the historic peak it reached after World War II.

\section{American Divorce: The Statistical Picture}

For those interested in the study of divorce, the state of divorce statistics is apt to be very disappointing. In all but six states, central collection of state divorce data did not begin before this century. Only one state, New Jersey, has central files of divorce records for the period before the Civil War. New Jersey established such files in 1795 , helped by the fact that a single statewide court, the Court of Chancery, heard all court actions for divorce. Chancery records go back to 1824 ; the first divorce record is dated 1826. There are records of legislative divorces in New Jersey from 1778 until the practice was abolished in 1844 . As Table 1 indicates, most of the early legislative divorces in New Jersey were granted to husbands. ${ }^{17}$ During the rest of the period covered by Table 1, most divorces (legislative and judicial) were granted to women, although the majority is not always large. Very few couples were divorced in New Jersey during this period; hence it is no surprise that there are large swings in the data. On the whole, the percentage of women plaintiffs is slightly less than it would be later in the century in New Jersey. ${ }^{\mathbf{1 8}}$.

In 1887 , in response to demands by the National Divorce Reform League for uniform divorce laws, the government undertook a statistical study of divorce. The study covered the period $1867-86$, and was followed by a second study, for the years 1887-1906. After 1906, divorce statistics were collected only sporadically. A survey of the period 1906-16 was planned, but U.S. entry into World War I interrupted the study; it was limited to 1916 alone. From 1922 through 1932, the Census Bureau conducted annual mail surveys of divorce statistics. From 1949 until the present, the National Center for Health Statistics ${ }^{19}$ has reported divorce statistics for whatever states choose to report them. The number of reporting states has varied somewhat, making

17 Three legislative divorces were granted in Maryland between 1790 and 1800 , all to husbands. Women received the majority of legislative divorces in Maryland from 1800 until the practice was abolished in 1850. M. K. Meyer, Divorces and Names Changed in Maryland by Act of the Legislature, 1634-1854 (undated manuscript, on file in Archives of New Jersey State Capitol).

18 Worth noting is an end-of-the-war drop-over 10 points-in the percentage of female plaintiffs. This Civil War phenomenon would be duplicated after World War II.

19 Formerly the National Office of Vital Statistics, now the Division of Vital Statistics of the National Center for Health Statistics. 
TABLE 1

Legistative and Judictal Divorces in New Jersey

\begin{tabular}{|c|c|c|c|c|c|c|c|c|c|}
\hline \multirow[b]{3}{*}{ Period } & \multicolumn{3}{|c|}{ Legislative Divorces } & \multicolumn{3}{|c|}{ Judicial Divorces } & \multicolumn{3}{|c|}{ Total Divorces Known } \\
\hline & \multicolumn{2}{|c|}{ Awarded to } & \multirow{2}{*}{$\begin{array}{c}\% \text { Awarded } \\
\text { Wife }\end{array}$} & \multicolumn{2}{|c|}{ Plaintiff } & \multirow{2}{*}{$\begin{array}{l}\% \text { of } \mathrm{Pl} . \\
\text { Wives }\end{array}$} & \multirow[b]{2}{*}{$\mathbf{H}$} & \multirow[b]{2}{*}{$\mathbf{W}$} & \multirow[b]{2}{*}{$\% \mathrm{~W}$} \\
\hline & $\mathbf{H}$ & $\mathbf{W}$ & & $\mathbf{H}$ & W & & & & \\
\hline $1778-1799$ & 8 & 5 & $38.5 \%$ & NA & NA & NA & 8 & 5 & $38.5 \%$ \\
\hline $1800-1819$ & 10 & 16 & $61.5 \%$ & NA & NA & NA & 10 & 16 & $61.5 \%$ \\
\hline $1820-1824$ & 10 & 14 & $58.3 \%$ & NA & NA & NA & 10 & 14 & $58.3 \%$ \\
\hline $1825-1829$ & 8 & 19 & $70.4 \%$ & 2 & 5 & $71.4 \%$ & 10 & 24 & $70.6 \%$ \\
\hline $1830-1834$ & 28 & 30 & $51.7 \%$ & 9 & 21 & $70.0 \%$ & 37 & 51 & $58.0 \%$ \\
\hline $1835-1839$ & 20 & 26 & $56.5 \%$ & 5 & 13 & $72.2 \%$ & 25 & 39 & $60.9 \%$ \\
\hline $1840-1844$ & 23 & 44 & $65.7 \%$ & 15 & 33 & $68.8 \%$ & 38 & 77 & $67.0 \%$ \\
\hline $1845-1849$ & - & - & - & 52 & 96 & $64.9 \%$ & 52 & 96 & $64.9 \%$ \\
\hline $1850-1854$ & - & - & - & 69 & 93 & $57.4 \%$ & 69 & 93 & $57.4 \%$ \\
\hline $1855-1859$ & - & - & - & 68 & 116 & $63.0 \%$ & 68 & 116 & $63.0 \%$ \\
\hline 1860 & - & - & - & 33 & 53 & $61.6 \%$ & 33 & 53 & $61.6 \%$ \\
\hline 1861 & - & - & - & 25 & 31 & $55.3 \%$ & 25 & 31 & $55.3 \%$ \\
\hline 1862 & - & - & - & 17 & 23 & $57.5 \%$ & 17 & 23 & $57.5 \%$ \\
\hline 1863 & - & - & - & 30 & 48 & $61.5 \%$ & 30 & 48 & $61.5 \%$ \\
\hline 1864 & - & - & - & 45 & 49 & $52.1 \%$ & 45 & 49 & $52.1 \%$ \\
\hline 1865 & - & - & - & 54 & 55 & $50.5 \%$ & 54 & 55 & $50.5 \%$ \\
\hline 1866 & - & - & - & 36 & 76 & $67.9 \%$ & 36 & 76 & $67.9 \%$ \\
\hline \multicolumn{10}{|l|}{ Total } \\
\hline $1778-1866$ & 103 & 156 & $60.2 \%$ & 468 & 690 & $59.6 \%$ & 571 & 846 & $59.7 \%$ \\
\hline
\end{tabular}

Sources: N.J., Index of Colonial and State Laws of New Jersey 1663-1903, at 390-94 (John Hood comp., 1905 ed.); New Jersey, Docket Book of the Chancery Court, vols. I.V (1824-1867).

historical comparisons difficult. The national Divorce Reporting Area (DRA) was formed in 1958. The number of reporting states has increased; it is now just over half of all states. ${ }^{20}$

From these statistics, supplemented with state reports and surveys of court records, it is possible to sketch a rough picture of changes in the ratio of female to male plaintiffs in divorce actions, at least for the past hundred years. Most available data report the percentage of divorces awarded women, not the percentage of female plaintiffs; the two terms can be, and often are, used almost interchangeably. There is no evidence that courts consistently ignore the petitions of one sex and award divorce to the other. Recent statistics show the two figures to be nearly identical and, most importantly, changing in the same direction. Furthermore, the overwhelming majority of divorces are, and have been, uncontested. What changes do occur between filing and judgment tend to cancel each other out. ${ }^{21}$

20 Hugh Carter \& Paul C. Glick, Marriage and Divorce, A Social and Economic Study 9 (1970).

21 While a small proportion of divorces are awarded wives in actions initiated by husbands, a similar proportion are awarded husbands in actions initiated by wives. Overall, there appears to be a slight 1.0 to $1.5 \%$ "bias" in favor of women. See Table 2, infra at 75. Although a few states permit courts to award divorces to both parties or to third parties, the number of such cases is miniscule and is ignored for the purposes of this study. 


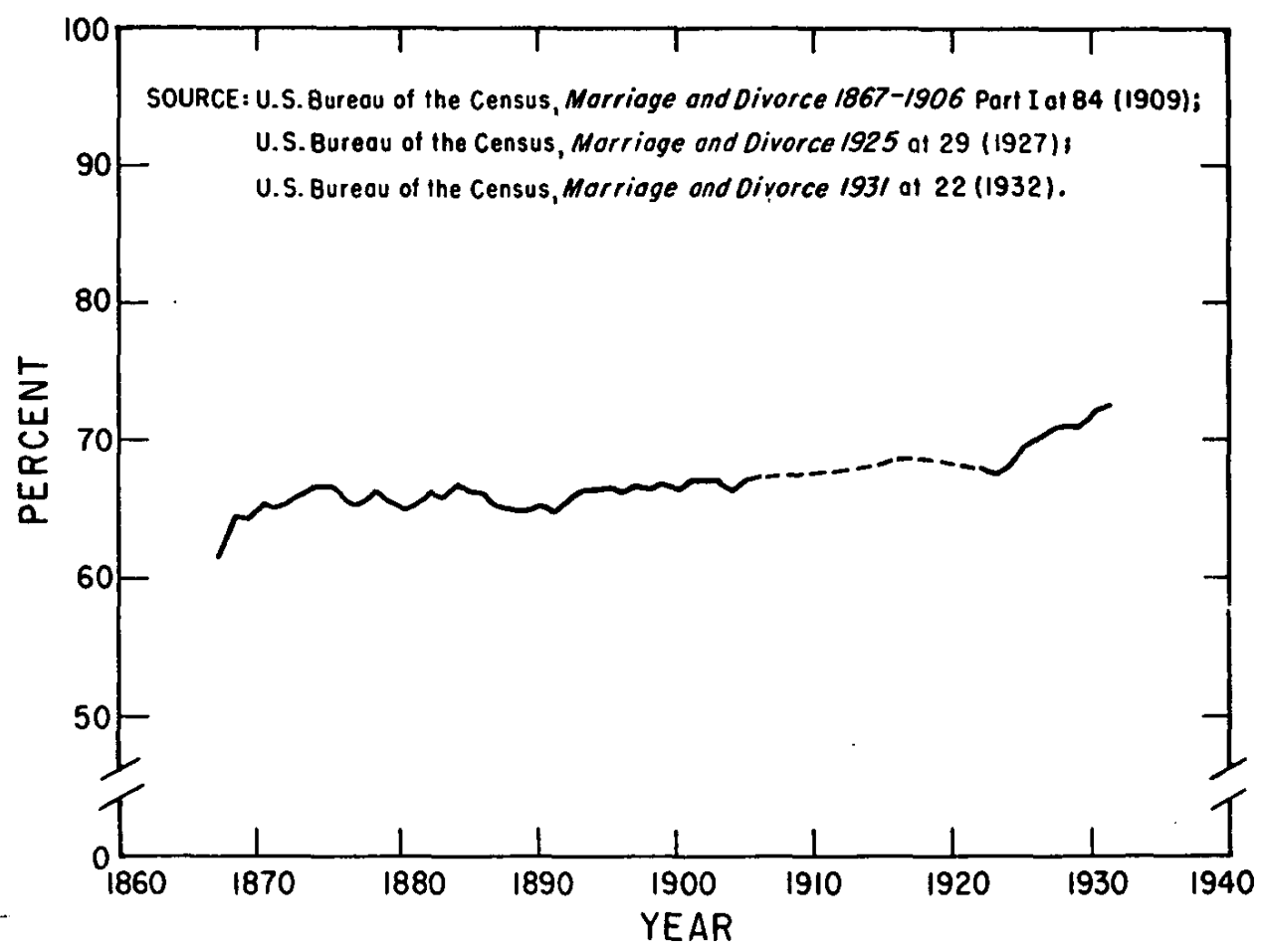

FIGURE 3

Percent of U.S. Divorces Awarded to Wives 1867-1931

\section{A. National Data}

In 1867 , less than 62 per cent of divorces were awarded to wives. This figure rose in the following decade to about two-thirds of all divorces. The percentage of divorces awarded wives remained about two-thirds, through the end of the second national survey in 1906. Annual data from 1922 through 1931 showed a slow but steady rise in this ratio from 68.0 per cent in 1922 to 72.8 per cent in $1931 .^{22}$

Striking differences appear, however, when the number of divorces granted, by sex, is analyzed in terms of the grounds for divorce. ${ }^{23}$ Only women allege "failure to provide" as a ground. Women were also the moving party in 90 per cent of all divorces granted for drunkenness during this period. They account for less than 60 per cent of the divorces granted for desertion. Neither of these figures changes much during the period 1867-1931. Men were the complaining (and winning) parties in the majority of adultery divorces between 1867 and 1906; but by 1931, more than 60 per cent of the divorces on grounds of adultery were awarded to women.

22 See Figure 4, infra at 71.

23 See Figure 5, infro at 73. 


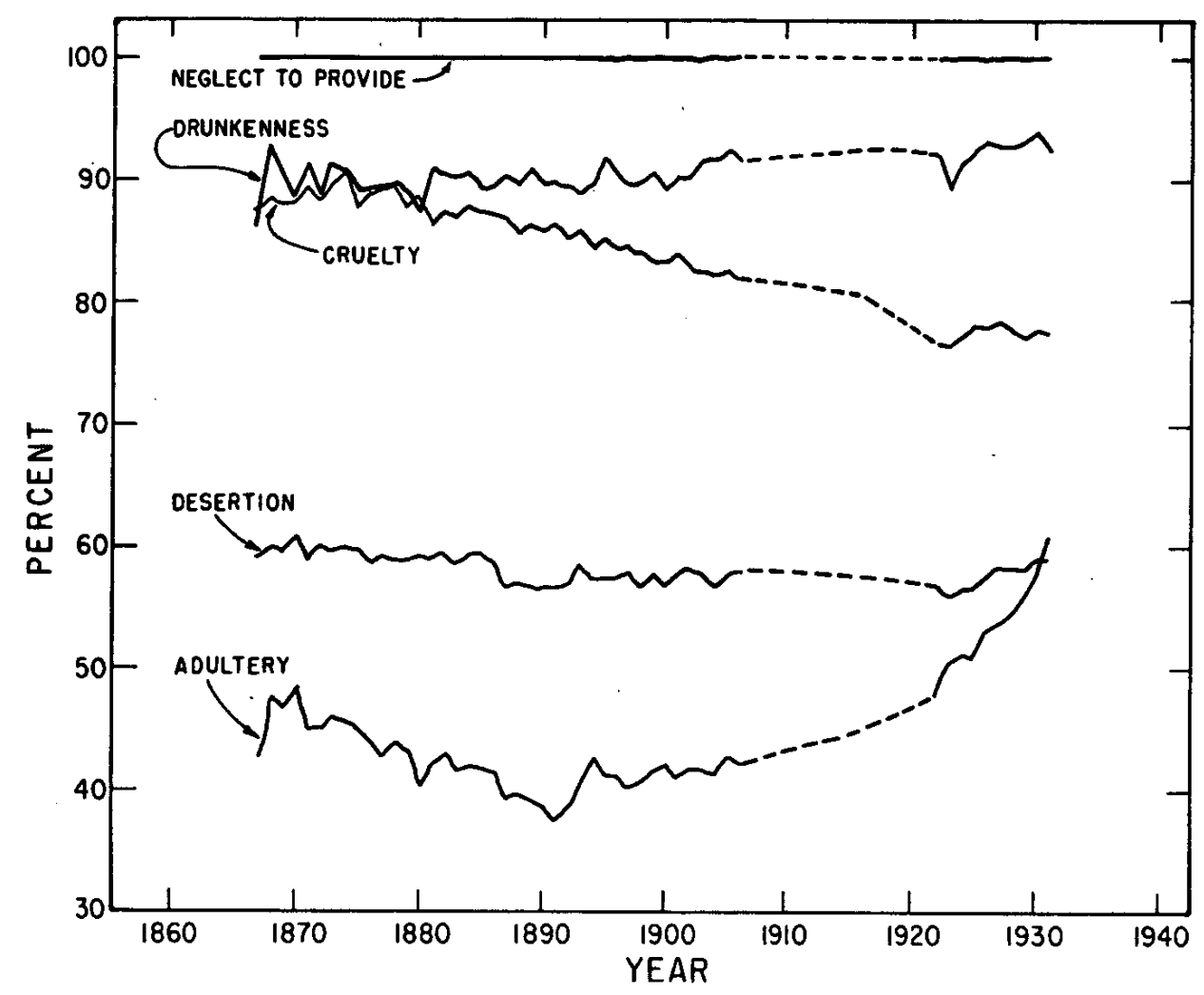

FigURE 4

Percent of U.S. Divorces Awarded Wives for Each Ground 1867-1931

\section{B. Regional Data}

The national data conceal striking regional differences. Figure 5 shows that wives were much less apt to be divorce plaintiffs in the South than elsewhere in the country. The percentages in the southern region range from 51.8 per cent to 57.5 per cent for the $1867-1871$ period. In the Middle Atlantic states the figure is somewhat higher, 61.7 per cent; in North Central regions it ranges from 62.8 per cent to 65.9 per cent; in New England it stands still higher at 68.2 per cent. Mountain and Pacific states awarded the highest percentage of divorces to wives, 74.9 per cent and 76.5 per cent, respectively.

Later, regional differences begin to narrow. The percentage of female plaintiffs rose in Southern states; in 1931 wives were awarded over two-thirds of all Southern divorces. Northern and Pacific states at that time awarded around three-fourths of all divorces to wives.

Overall, during the period 1867-1906 about two-thirds of all U.S. divorces were awarded to wives-in Southern states just over half, in Northern states about two-thirds, in the West about three-fourths. During the 1920's, the 
national figure climbed until slightly less than three-fourths of all U.S. divorces went to women in 1931.

\section{State Data}

Differences in the percentages of divorces awarded wives become even more striking if we look at individual states. In some Southern states, in the nineteenth century, men were granted well over half of all divorces. ${ }^{24}$ In Mississippi, wives sought and won only 41.6 per cent of the divorces granted, in North Carolina their share was 41.8 per cent, at a time when many Northern and Western states, particularly those with less stringent divorce laws, granted between two-thirds and three-fourths of their divorces to women. ${ }^{25}$ Again, the differences between states had narrowed greatly by 1931 .

National information on the "winners" at divorce dries up after 1931; but a number of individual states do report this information, particularly after World War II. From 1949 until 1965, the information was included in the summary of state divorce reports, published by the National Center for Health Statistics. ${ }^{26}$ The figures show little change in the percentage of divorces granted each sex in the reporting states during this period. Wives won slightly fewer than three of every four U.S. divorces between 1949 through 1965. There were no longer any consistent regional differences among reporting states.

More recent data reveal two interesting relationships. After World War II, there was a sharp, temporary drop in the percentage of wives granted divorces. In Maine, the drop was nine percentage points, in Massachusetts six, in Florida ten, in Iowa seven. Within a few years, however, the percentages returned to their original levels. The source of this single squall seems obvious: men returning from war and reshuffling their marital arrangements. In Australia, a similar drop of 10 per cent in the percentage of female plaintiffs took place at the end of World War II. ${ }^{27}$

From 1960-1965, Divorce Reporting Area states reported information on the sex of plaintiff in divorce and annulment actions, in addition to data on the party awarded the divorce. As might be expected, the two figures are nearly identical. Differences are quite consistent from year to year. The share of divorces and annulments awarded wives is from 1.0 to 1.6 percentage

24 See Figure 7, infra at 76.

25 Id.

26 U.S. National Center for Health Statistics, Marriage and Divorce in the U.S. (1949-1965).

27 Prior to World War II more than $54 \%$ of Australian divorce plaintiffs were women. By 1944 this percentage had dropped to $44 \%$; by 1950, it was back above $55 \%$. Today about $62 \%$ of divorce plaintiffs in Australia are wives. Australia, [Commonwealth] Bureau of Census and Statistics, Official Yearbook of the Commonwealth of Australia, vols. $32-58$ (1939-72). 


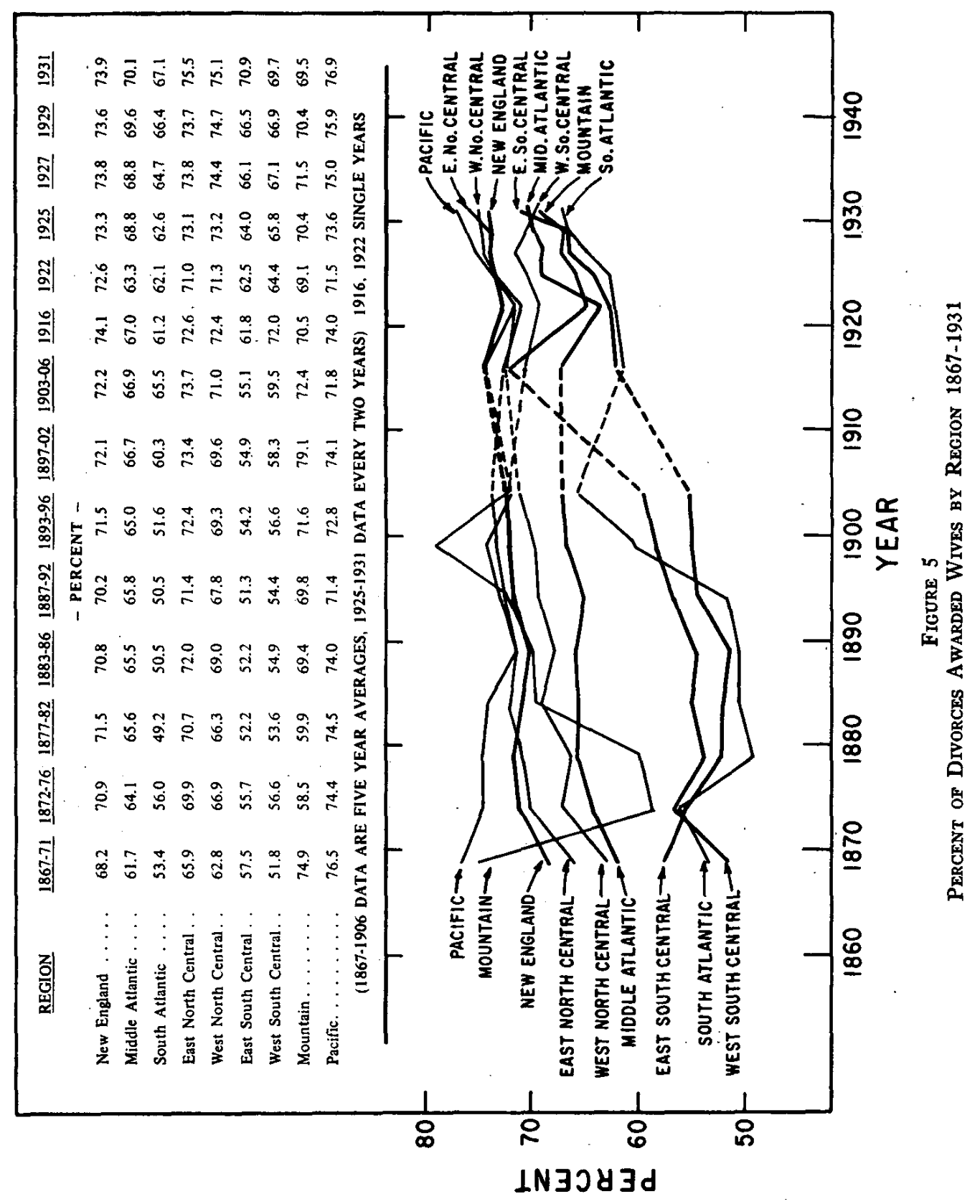




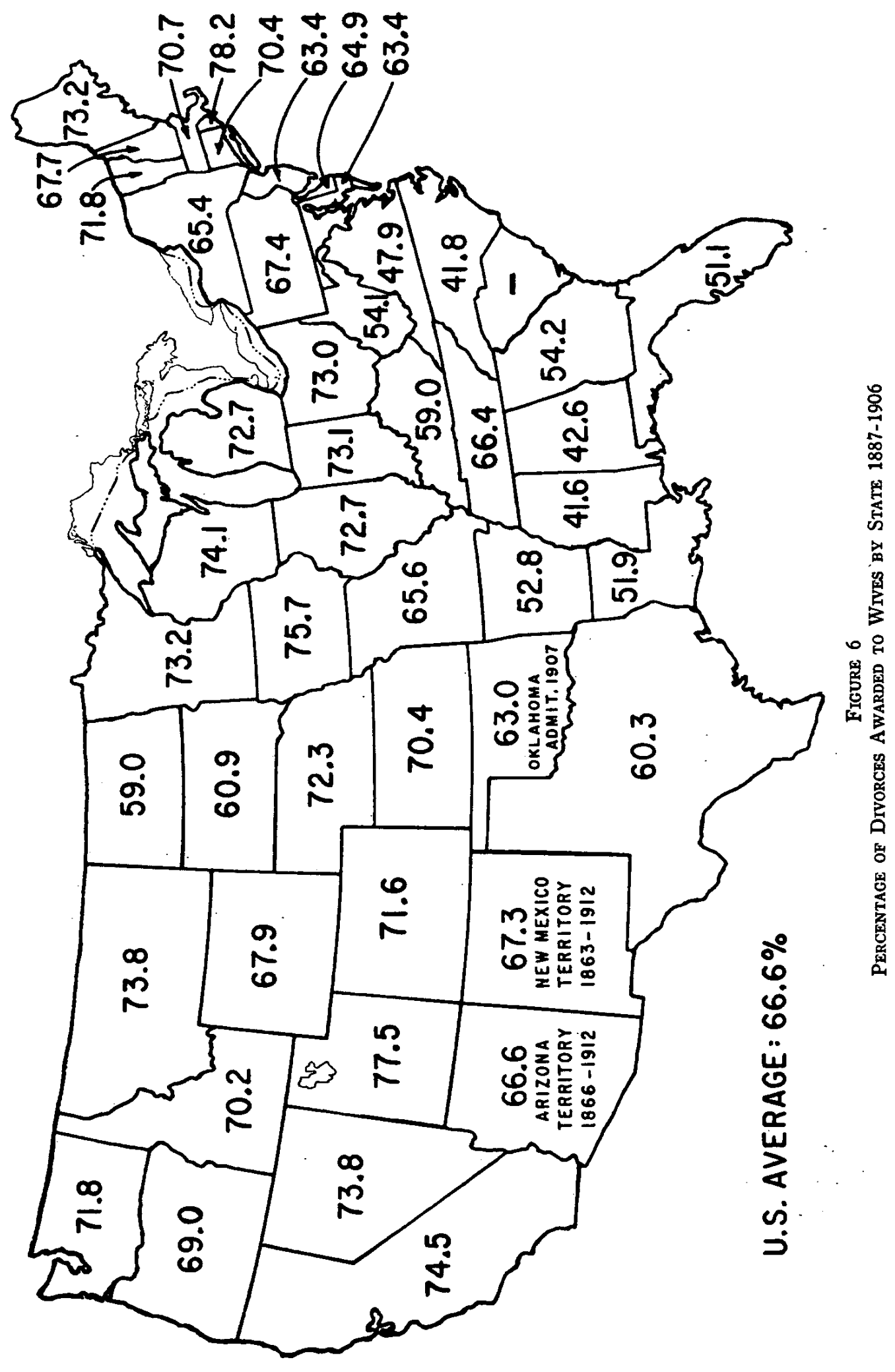


TABLE 2

Percentage of Divorce Puantiffys Who are Women and Percentage of Divorces Awarded Wives-DRA States 1960-65

\begin{tabular}{lcccc}
\hline \hline Year & No. of States & $\begin{array}{c}\text { Percentage of } \\
\text { Divorce Plaintiffs } \\
\text { Who Are Wives }\end{array}$ & $\begin{array}{c}\text { Percentage of } \\
\text { Divorces \& } \\
\text { Annulments } \\
\text { Granted Wives }\end{array}$ & $\begin{array}{c}\text { Percentage } \\
\text { Point } \\
\text { Difference }\end{array}$ \\
\hline 1960 & 18 states & $70.3 \%$ & $71.3 \%$ & 1.0 pts. \\
1961 & 20 states & $72.1 \%$ & $73.3 \%$ & 1.2 pts. \\
1962 & 21 states & $71.2 \%$ & $72.8 \%$ & 1.6 pts. \\
1963 & 22 states & $72.2 \%$ & $73.7 \%$ & 1.5 pts. \\
1964 & 22 states & $71.3 \%$ & $73.0 \%$ & 1.3 pts. \\
1965 & 22 states & $71.4 \%$ & $73.0 \%$ & 1.6 pts. \\
\hline
\end{tabular}

Source: Vital Statistics of the United States, 1960 through 1965, vol. 3, Marriage and Divorce (U.S. Nat'l Center for Health Statistics, 1964-68).

points higher than the percentage of plaintiffs who are wives, as indicated by Table 2.

There are no national statistics on winning party after 1965 . Some state agencies continue to collect this information. But some no-fault states have stopped collecting the data, perhaps because divorce is no longer an adversary proceeding. California, however, continues to gather the information. From 1966. through 1969, more than 78 per cent of California's divorce plaintiffs were women. No-fault divorce was introduced in 1970, and the percentage quickly dropped to 71.5 per cent. By 1974 , fewer than 68 per cent of petitioners for dissolution in California were women.

New Jersey too continues to report sex of parties in divorce cases. New Jersey revamped its law in 1971; it added separation for eighteen months -a "no fault" concept-as grounds for divorce. Within 12 months, the number of divorce petitions in the state increased by 70 per cent. As in California, the percentage of men who won divorces rose quite noticeably; women won 70.2 per cent of the divorces in 1971 but only 61.2 per cent in 1972; this percentage rose somewhat in 1973 and 1974, but not to the level of the years before the statute was revised. Table 3 summarizes the California and New Jersey data.

\section{Who Sues For Divorce-AND WhY?}

What are we to make of this history? Generally speaking, we notice that the percentage of wives who sue and win divorce correlates with the divorce rate. That is, the higher the divorce rate, the more likely that the woman will take the first formal step. Figures 6 and 7 show this plainly for the nineteenth century. This, however, ceases to be true in the so-called no-fault states after 1970. Here the divorce rate rises (perhaps only temporarily), but a higher percentage of the filers are men. 

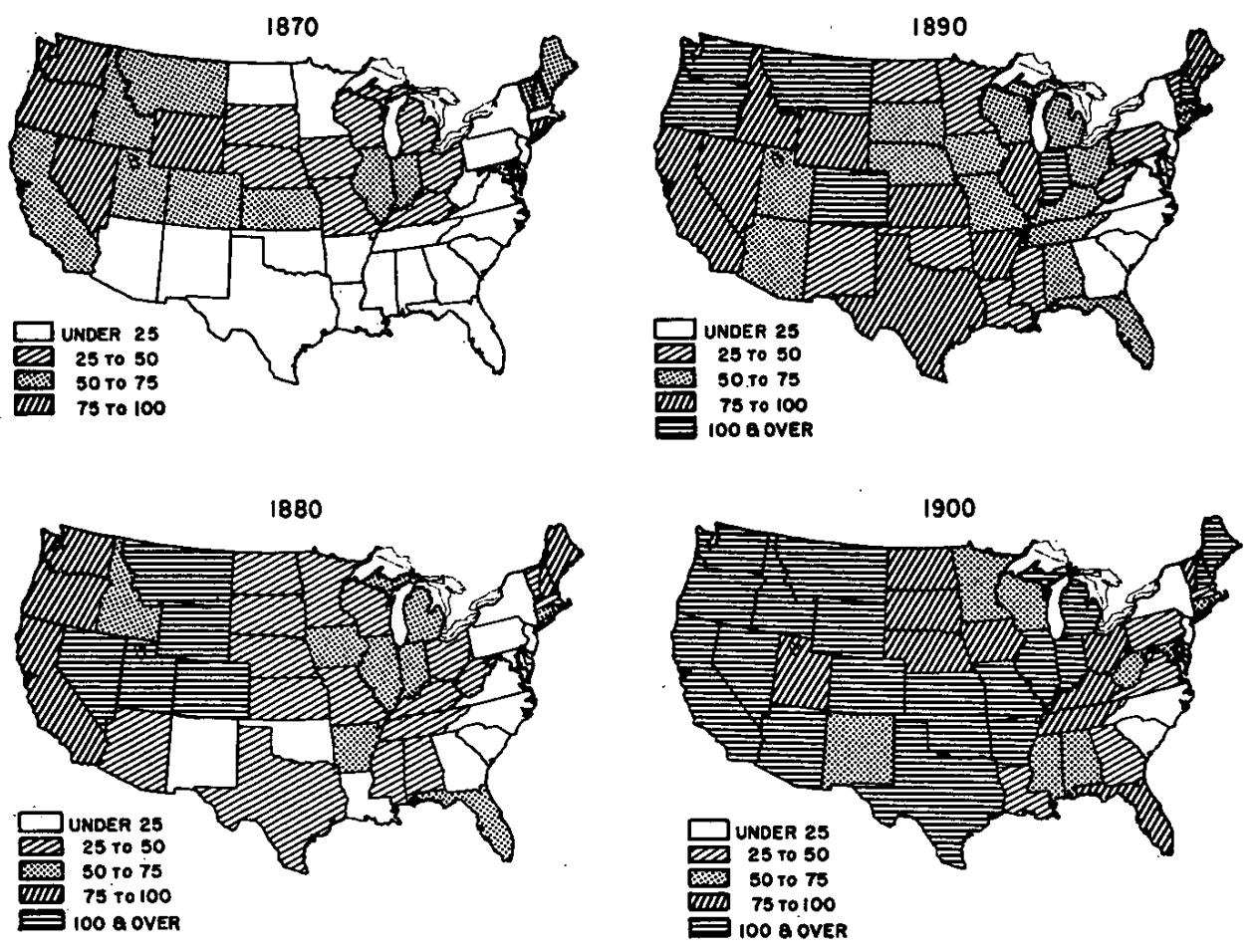

SOURCE: U.S. Bureau of the Census, Marriage and Divorce 1887-1906 Part 1 at 17 (1907)

FIGURE 7

Divorces Per 100,000 Population by State

\section{A. The First Stage: "Fault"}

The data suggest, roughly, three stages in the history of divorce. In the first stage, divorce is difficult and rare. Only a few grounds are available. There is social pressure against divorce, and divorce bears a heavy stigma. Women are generally subservient to men. Middle-class women on the whole rarely take part in the work force. A divorced woman has an awkward role in society. Divorce is confined, as a practical matter, to a few people, mostly upper class. As far as we can tell, the grounds alleged in court are grounded in reality. That is, if adultery is the complaint, the defendant really was an adulterer or adulteress, and adultery was either the cause or at least the excuse for the plaintiff's case.

In this period, we do not expect women to predominate as plaintiffs. In the first place, divorce is an extreme step; it brings disgrace. No doubt many women would have been pleased to get rid of their husbands; social pressure 
TABLE 3

Percentage of Divorce Platntiffs Who Are Women-California Percentage of Divorces Granted to Wives-New Jersey, 1966-74

\begin{tabular}{|c|c|c|c|}
\hline Year & California & New Jersey & \\
\hline 1966 & $78.3 \%$ & $68.1 \%$ & \\
\hline 1967 & $78.9 \%$ & $67.9 \%$ & \\
\hline 1968 & $78.6 \%$ & $67.6 \%$ & \\
\hline \multirow[t]{2}{*}{1969} & $78.3 \%$ & $67.8 \%$ & \\
\hline & No-Fault & & \\
\hline 1970 & $71.5 \%$ & $68.9 \%$ & \\
\hline \multirow[t]{2}{*}{1971} & $70.6 \%$ & $70.2 \%$ & \\
\hline & & - & $\begin{array}{l}\text { No-Fault } \\
\text { Grounds added }\end{array}$ \\
\hline 1972 & $69.4 \%$ & $61.2 \%$ & \\
\hline 1973 & $67.7 \%$ & $64.9 \%$ & \\
\hline 1974 & $67.3 \%$ & $64.1 \%$ & \\
\hline
\end{tabular}

Source: Unpublished data from the California Bureau of Vital Statistics obtained in interviews with Robert Milke, statistician, Sept. 1974, and Louis Manfeld, statistician, Sept. 1975, California Bureau of Vital Statistics, Sacramento; California; New Jersey, Administrative Office of the Courts, Annual Report, 1956-57 through 1973-74. California data are for calendar years; New Jersey's for fiscal years.

and an uncertain future held them back. Men sued for divorce to get rid of bad wives-wives who broke the code of morality. Divorce was costly; ordinary people used desertion, infidelity, and informal cohabitation to get around an inconvenient marriage.

The figures for the archaic, preindustrial South-in the nineteenth century-are the clearest evidence of this stage. In theory, one might expect to find similar figures for the North, before the Civil War. The data, however, are fragmentary and disappointing. The figures from New Jersey support the hypothesis very weakly. Divorce was so uncommon in New Jersey that it is hard to base much on the figures. English data, however, are quite suggestive. Divorce was uncommon in England even after the reforms of 1857. For the year ending October 31, 1890, there were 534 petitions for divorce. Husbands filed most of these -318 or 59.6 per cent. Well into this century, the divorce rate was extremely low, and petitioners were mainly husbands. ${ }^{28}$ By way of contrast, in 1972, 109,822 petitions for divorce were filed; 71,077 of these (64.7 per cent) by wives. In matters of divorce, therefore, England has been more "backward" than the United States. The first stage, in which

28 The figures for 1890 are from Civil Judicial Statistics 1890, C. 6443, at xxix, 25 (in Gt. Brit., Parl. Papers 1890-91, vol. xciii); see also Civil Judicial Statistics 1910, Cd. 6047, at 25, tab. A (in Gt. Brit., Parl. Papers 1912-13, vol. cx, at 187).

English law, to be sure discriminated against wives who wanted divorces; adultery was, until 1923, grounds for divorce against a woman, but against a man, adultery alone would not do; there had to be some additional matrimonial offense. John Eekelaar, Family Security and Family Breakdown 33 (1971); Matrimonial Causes Act 1857, 20 \& 21 Vict. ch. 85, $\$ 27$. This double standard is probably not a sufficient explanation of the imbalance-although the attitude underlying it may well be. 
divorce is uncommon and more strongly male-centered, lasted far longer than in the States.

\section{B. The Second Stage: "Fiction"}

During the second period, social attitudes toward divorce seem to have changed. Divorce rates rose steadily, and, as the period progressed, social disapproval of divorce and the divorced woman began to ebb somewhat. More women left home to enter the labor force. The nature of marriage, too, was altered. As William L. O'Neill has pointed out, people expected more out of marriage than in traditional eras; ${ }^{29}$ a wife was to be more than sex partner, servant, and nursemaid; a husband was to be more than a breadwinner and protector. Marriage was supposed to be a partnership of love. This was presumably a minority view, which slowly percolated downward and outward in society. As it spread, divorce was no longer restricted to the upper class. Divorce was democratized.

New demands on marriage increased the demand for easier divorce. But changing expectations cannot alone account for loose divorce laws. No doubt Italy too felt the pull of modern marriage, at least to a degree; but divorce remained stubbornly outlawed. What was strongly felt in the United States was a demand for legitimization of status. This can be explained in two ways. In the first place, divorce was probably less stigmatic than sex outside of marriage. Men and women who had left their old partners wanted to form new families, have children, live normal economic and social lives. They saw no reason why the law should not let them do so, legitimately. Then, too, ownership of property was widely diffused in this society, and the status of marriage was a crucial determinant of property rights and deeply affected titles to land, as well as inheritance and land transfer. The feminist movement no doubt also affected the law of marriage and divorce. Between 1870 and 1930 , too, the percentage of women in the labor force nearly doubled. By the end of the period, about one-fourth of all women over the age of 16 were workers.

Perhaps the strongest of these various forces pressing for easy divorce was the need and desire to settle doubts about property rights. Without divorce, possession could become disturbed, inheritance confused, land titles clouded. This practical need conflicted, however, with a moral aversion to easy divorce, an aversion with powerful supporters among religious and ethical leaders. The result was a cowardly but, on the whole, rather workable compromise. The laws remained, in general, quite stern-on the surface. Migratory divorce (the escape hatch in Reno, for example) plus widespread collusion meant that divorce was available on demand, and at a price; but the legal

29 William L. O'Neill, Divorce in the Progressive Era 12 (1967). 
system did not have to admit what was going on. The law of divorce became a fiction.

A fiction, however, of a particular type. Formally speaking, divorce depended on fault: a divorce case was one in which an innocent party demanded freedom from a sinner's clutches. Where husband and wife agreed, for whatever reason, that their marriage was dead, it was the wife who would have to file the lawsuit. In the first place, it was less damaging to accuse a man of cruelty, desertion, or adultery than to accuse a woman of these acts. In the second place, the wife would of course keep the children; the husband would pay. Hence the wife in form had to play the innocent party, whether she was in fact or not.

In this second period, then, wives were the dominant plaintiffs; and divorce was as fictional as ejectment in the middle ages. Collusion is of necessity a secret, but the transformation of divorce left plain traces in the statistical record. As demand for divorce rose, the grounds alleged for divorce changed; they corresponded less and less with the real or underlying causes. In 1931, the allegation of adultery was one-fourth as common as in 1867; cruelty, however, was four times as frequent..$^{30}$ Cruelty is one of the dazzling success stories of family law. This is because cruelty proved so useful during the fiction phase of divorce. Adultery was a difficult and embarrassing allegation; it required obnoxious proof. Desertion was plain matter of fact-either a husband had stayed away for long enough, or he had not. Cruelty, however, was easily alleged and in any event a matter of judgment. ${ }^{31}$ Again, English statistics are illuminating. In 1972, of 109,822 petitions for dissolution of marriage, 30,922 alleged adultery as sole grounds. Only slightly more women $(16,600)$ than men $(14,260)$ complained of adultery. Very different, however, were the 25,424 petitions for divorce on the grounds of "unreasonable behavior." Wives filed almost all of these $(22,886)$, husbands only a handful $(2,538)$. It is hard to resist the conclusion that an English couple, on the lookout for a friendly or collusive divorce, would arrange to file on the grounds of unreasonable behavior; and the wife would act as moving party. Data for the United States permit similar conclusions: Note particularly the Southern states in the late nineteenth century.

In short, during the second period, wives filed for divorce far more often than husbands, out of chivalry, respect for social convention, and con-

30 In Ohio, adultery had fallen from $15 \%$ of the cases to $2 \%$, between 1867 and 1930 ; "gross neglect of duty" rose in the same period from about $5 \%$ to over $60 \%$. 2 Marshall \& May, supra note 11, at 314-16.

31 These remarks do not hold, of course, for New York, which until the 1960s did not allow divorce except for adultery. Here, as we have seen, a grosser form of collusion flourished, with manufactured evidence. 
venience; and because the fault form of divorce made this a practical necessity in order to reach desired results. Couples used looser and more ambiguous grounds for divorce, and the divorce rate continued to rise. New grounds, such as cruelty, accounted for most of the rise in divorce petitions; the older, stricter, more classical grounds-such as adultery-grew at a much less rapid rate. Even here there were changes. In 1890, men were the moving party in more than 60 per cent of the divorces for adultery. In 1931, women were the moving parties in more than 60 per cent. This may reflect a change in attitudes about sex roles; more likely it reflects the demand for divorce in states, like New York, which allowed virtually no grounds besides adultery. Elsewhere, the triumphant ground was cruelty. Indeed, the flourishing of cruelty allows us to date with some precision the rise of the collusive divorce.

North-South differences in the statistics are, of course, a striking fact. Divorce was more difficult to get and less common in the South. Fewer women were in the labor force; the social penalty which a divorced woman had to pay probably was greater than in the North. Southern divorce remained basically an upper-class phenomenon, at a time when divorce was becoming classless in the North. ${ }^{32}$

There is a connection between a high percentage of divorces granted to women and easy divorce law. There were high percentages in the late nineteenth century in the lax states of the West and North. But there were somewhat more male plaintiffs in states that operated divorce mills. Men were more likely than women to travel in search of divorce in the last century. States with loose residency requirements-the Dakotas in the 1890s, for example-showed somewhat higher percentages of plaintiff-husbands than their neighbors. In Northern states with strict divorce laws-New York and New Jersey, for example-fewer divorces were granted to wives than in neighboring states with easier laws. A high percentage of wife-plaintiffs is apparently even more closely related to easy laws than to actual divorce rates. New England, for example, had liberal divorce laws-but a relatively low divorce rate. The percentage of divorces granted to women in New England has always been high-between two-thirds and three-fourths of all divorces.

\section{The Third State: "Freedom"}

This brings us to the third and last period, a period just now beginning, the period of no-fault divorce. The new laws have revolutionized the form of divorce. Fault has been stripped away. The process is easier and cheaper.

32 The divorce rate today is more than twice as high among the lower than the middle class. Donald G. McKinley, Social Class and Family Life 114 (1964). 
Nearly 20 per cent of the uncoupling parties, in a sample taken in one California county, dispensed with the services of a lawyer ${ }^{33}$ No doubt the revolution is largely one of form; but it ratifies a process long under way in society, in the course of which divorce has lost much of its stigma. Formal change of course may accelerate the process. In addition, the "liberation" of at least some women, and some tendency to shift roles within families, may bring about a slight increase in the number of husbands who want and accept custody of children. In California, property laws have been reformed, in the name of a fairer division between husband and wife. This, too, may make it more a matter of indifference who files, compared to years before 1970. In the no-fault states, one might predict that somewhat more men would file for divorce than in the fault states; the figures for California and New Jersey confirm this prediction. ${ }^{34}$ The five-year California experience indicates that the trend is continuing.

The rise and fall of this single indicator provides an interesting case study in American legal culture. Divorce has always been a complex problem. Tension between what large numbers of people wanted, and what moral leadership thought the law should be, twisted divorce into its characteristic fictional shape. There is some reason to believe that wide areas of law in the nineteenth century responded to a similar dynamic. That is, formal official law reflected strict, high-grade moral norms; actual legal process responded to quite different demands. This was true, perhaps, of criminal law, where crimes against morality were strongly condemned on paper and in the penal codes, but were, in general, let alone so long as they were done quietly and in private. ${ }^{35}$ Perhaps it was also true of the civil law, as well-for example, the law of contract and torts, where tissues of neat, logical doctrine were bent at the trial-judge and jury level in directions that formal law would never

33 The county is San Mateo County, in the San Francisco Bay Area. The unpublished research on this point was done by Robert McCulloh, Stanford Law School. Virtually no one, before the changes in the law, tried to obtain a lawyerless divorce.

34 Divorce records were also sampled in Florida and Iowa, two other recent no-fault states, but which do not keep statewide records. Florida adopted no-fault in 1971; Iowa in 1970. Of 200 Florida divorce certificates examined in 1974 (a .4\% sample), $71.5 \%$ of the petitioners were women. This is slightly below the last statewide report, which showed that $73.4 \%$ of Florida divorces were awarded to women in 1969 . (Sampling was done by William DeGrave, Florida Dept. of Health \& Rehabilitative Services. Letter from William DeGrave to Robert V. Percival, Feb. 20, 1975.) A sample of dissolution records in Polk County, Iowa (Iowa's most populous county) revealed a slight decrease in the percentage of wives filing for divorce. During the first three months of $1969,80.7 \%$ of the 591 divorce cases filed in Polk County were initiated by wives. Under the no-fault procedures during the first three months of $1972,78.3 \%$ of the 540 dissolution petitions filed were initiated by women. In both cases, the differences were in the predicted direction, though too small to be statistically significant.

35 On this point, see Lawrence M. Friedman, Notes Toward a History of American Justice, 24 Buffalo L. Rev. 111 (1974). 
have recognized. What is characteristic of this century, then, is the strain toward legitimating what had before been illegitimate but tacitly accepted. Law in the twentieth century is like the man who finally marries his mistress. This movement for legitimation, then, is one source of the no-fault divorce. But legal change, even when it is little more than ratification, may set up its own field of force. 